\title{
Natural trophic variability in a large, oligotrophic, near-pristine lake
}

Talia Young ${ }^{*}, 1$, Olaf P. Jensen ${ }^{2}$, Brian C. Weidel ${ }^{3}$ and Sudeep Chandra ${ }^{4}$

${ }^{1}$ Graduate Program in Ecology \& Evolution, Rutgers University, New Brunswick, NJ 08901

${ }^{2}$ Department of Marine \& Coastal Science, Rutgers University, New Brunswick, NJ 08901

3 USGS Great Lakes Center, Lake Ontario Biological Station, Oswego, NY 13126

${ }^{4}$ University of Nevada, Reno, NV 89557

* Corresponding author: tyoung@marine.rutgers.edu, (848) 228-2542

Running title: Natural trophic variability in a near-pristine lake 


\begin{abstract}
Conclusions drawn from stable isotope data can be limited by an incomplete understanding of natural isotopic variability over time and space. We quantified spatial and temporal variability in fish carbon and nitrogen stable isotopes in Lake Hövsgöl, Mongolia, a large, remote, oligotrophic lake with an unusually species-poor fish community. The fish community demonstrated a high degree of trophic level overlap. Variability in $\delta^{13} \mathrm{C}$ was inversely related to littoral-benthic dependence, with pelagic species demonstrating more $\delta^{13} \mathrm{C}$ variability than littoral-benthic species. A mixed effects model suggested that space (sampling location) had a greater impact than time (collection year) on both $\delta^{13} \mathrm{C}$ and $\delta^{15} \mathrm{~N}$ variability. The observed variability in Lake Hövsgöl was generally greater than nonanthropogenically mediated isotopic variability documented in other lakes, similar to isotopic shifts attributed to introduced species and less than shifts attributed to anthropogenic chemical changes such as eutrophication. This work complements studies on isotopic variability and changes in other lakes around the world.
\end{abstract}

Key words (2-6): Lake Khovsgol; Lake Khuvsgul; pristine; stable isotope variability; littoral-benthic; Mongolia 


\section{Introduction}

Stable isotope analysis is a powerful tool for elucidating the effects of humans on aquatic ecosystems, useful both for documenting change over time due to anthropogenic impacts and for quantifying ecosystem disturbance. Historical isotope studies have illustrated trophic shifts resulting from the introduction of smallmouth bass and rock bass into Canadian lakes (Vander Zanden et al., 1999), sea lamprey and rainbow smelt into Lake Superior (Schmidt et al., 2009), and lake trout and Mysis shrimp into Lake Tahoe (Vander Zanden et al., 2003). Carbon stable isotope analysis has been used to illuminate a shift in Lake Tahoe toward pelagic primary production as a result of anthropogenic eutrophication (Chandra et al., 2005b). Nitrogen stable isotopes have been used to monitor or distinguish sources of anthropogenic nitrogen in lakes (Hoffman et al., 2012), and as indicators of habitat change or restoration (Lake et al., 2001).

Interpretation of these stable isotope data remains limited, however, by our incomplete understanding of natural isotopic and trophic variability in the absence of anthropogenic disturbance. For instance, what is the significance of a trophic shift in lake trout after the introduction of sea lamprey if we do not know how much trophic variability lake trout might have demonstrated over time in the absence of sea lamprey? A number of studies have quantified temporal and spatial isotopic variability in a range of lakes, such as Lake Superior (Harvey and Kitchell, 2000), Lake Winnipeg (Hobson et al., 2012), Lake Jyväsjärvi (Syväranta et al., 2006), Lake Kyoga (Mbabazi et al., 2010) and Lake Erie (Guzzo et al., 2011). These studies found a range of interannual and among-site isotopic variability in a wide variety of fish species. But all of these study systems have been anthropogenically modified - and in some cases, quite extensively so - by commercial 
fishing, development, introduced species, and dams, making it difficult to assess background variability without these human impacts.

Understanding natural trophic variability is critical not only for interpreting past anthropogenic effects on ecosystems, but also for managing current resources and planning for such effects in the future. Ecosystem and resource management is often conducted in the context of the "range of natural variability" (Landres et al., 1999), and yet scientists and managers struggle to determine the extent of that range, frequently relying on coarse-scale paleo-data, or long-term data sets begun only after major anthropogenic impacts, as proxies for such "natural variability" (Morgan et al., 1994; Smol, 1992). Increases in variability have been shown in both laboratory and field contexts to act as an indicator for large-scale ecological regime shifts (Carpenter and Brock, 2006; Carpenter et al., 2011; Dakos et al., 2009) and stable isotope ratios have been suggested as an effective earlydetection indicator for environmental change (Williams et al., 2007). But any changes in variability may be hard to detect over background noise without a better understanding of baseline variability.

In this study, we quantified natural trophic variability in the near absence of anthropogenic effects, using carbon and nitrogen stable isotopes of a fish community in a near-pristine system. Our study lake, Lake Hövsgöl (Fig. 1), is a large, deep, oligotrophic lake in Mongolia, the least densely populated country in the world. Lake Hövsgöl is subject to minimal commercial or recreational fishing or development, and has only ten species of fish (including the endemic and endangered Hövsgöl grayling (Thymallus nigrescens)) (Ocock et al., 2006; Sideleva, 2006), offering an unusually pristine and ecologically simple 
study system. In addition to describing the food web of this system, we focused on two more general questions about isotopic variability:

1. Do we see any patterns of isotopic variability related to life history and ecological characteristics of a species, such as size, trophic level and trophic guild (e.g., planktivory vs. piscivory)? We might, for example, expect to see decreased $\delta^{13} \mathrm{C}$ variability among piscivores, since any differences in $\delta^{13} \mathrm{C}$ in prey fish would be integrated in their piscivore consumers.

2. Which has greater impact on isotopic variability: collection year (temporal or interannual variability) or collection location (spatial variability)? In other words, are spatial and temporal variability comparable in this system? Other work - using other metrics - has suggested that spatial variability exceeds temporal variability (Kratz et al., 2003; 1995; Roset et al., 2007).

\section{Methods}

Study site

Lake Hövsgöl (51.0 N, 100.5 E) (also spelled Khovsgol and Khuvsgul) is located in northern Mongolia, just south of the Russian border, $1645 \mathrm{~m}$ above sea level (Fig. 1). The lake is the nineteenth largest in the world by volume (383 km³), $136 \mathrm{~km}$ long and $20-37 \mathrm{~km}$ wide, with a surface area of $2760 \mathrm{~km}^{2}$, a mean depth of $138 \mathrm{~m}$ and maximum depth of 262 m (Goulden et al., 2006; Herdendorf, 1982). The lake is dimictic, ice-covered from November to June, and ultra oligotrophic, with Secchi depths ranging from 14 to $30 \mathrm{~m}$ (Goulden et al., 2006; Goulden and Boldgiv, 2002; Kozhova and Kobanova, 2006). The lake is fed by approximately 96 tributaries and drains into the Eg River at the south end of the 
lake, which joins the Selenga River and flows into Lake Baikal (Goulden et al., 2006). Lake Hövsgöl lies about $200 \mathrm{~km}$ southwest of Lake Baikal and shares the same geological formation (the Baikal rift system), but is estimated to be much younger than Lake Baikal: 25 million years old compared to Baikal's 20-65 million years old (Goulden et al., 2006). Furthermore, geological data suggest that primary productivity in Lake Hövsgöl may have halted completely during the last glacial maximum, so that its ecosystem may only be about 10,000 years old, repopulated from nearby bodies of water after the glaciers receded (Goulden et al., 2006; Karabanov et al., 2004). This event may explain the paucity of fish species inhabiting the lake (Karabanov et al., 2004).

Ten fish species are known to inhabit the lake (Table 1), including Baikal omul (Coregonus autumnalis migratorius), which were introduced to the lake twice (in 1956-7 and 1980) (Dulmaa, 1999; Manchin and Dgebuadze, 2010), but are nonetheless rare or perhaps extirpated, as we did not encounter this species in five years of fish community sampling.

Lake Hövsgöl was established as a national park in 1995, and remains largely free of direct human impacts. The region is half a day's drive on unpaved roads to the nearest city (of less than 40,000) and the total population living around the lake is about 5000 (“Population and Housing Census of Mongolia," 2010). A few tourist camps line the southwestern shore, and sparse mobile herding communities graze livestock along portions of both the eastern and western shores. None of the tributaries are dammed, and the lake is subject to limited fishing from shore. The region has, however, experienced unusually rapid warming in the last few decades (mean increase of $2.1^{\circ} \mathrm{C}$ over the past 70 years) (Dagvadorj et al., 2009). 
Sample collection

We collected tissue samples from six of the ten fish species known to occupy the lake (Table 1) from one to seven littoral locations around the lake in July 2006, 2009, 2011, 2012 and 2013 (mean n=14 samples/species/year, total samples analyzed=430) (Fig. 1, Table 2, Electronic Supplementary Material (ESM) Table S1). We were not able to collect every species at every location in every collection year. We collected Hövsgöl grayling at nine pelagic locations in addition to the littoral locations. We also collected Baikal grayling (Thymallus arcticus baicalensis), Siberian stone loach (Barbatula toni) and spiny loach (Cobitis melanoleuca), but did not include them in our analysis because the samples were not distributed adequately across years and locations. In 2006, we differentiated Hövsgöl grayling from Baikal grayling using visual identification characteristics. In all other years, we differentiated Hövsgöl grayling from Baikal grayling using gillraker counts, based on Berg (1962) and the distribution of our samples; those with greater than 23 gillrakers were designated Hövsgöl grayling (K. Olson, unpubl., T. Krabbenhoft, unpubl.).

Collection methods are described in greater detail by Ahrenstorff et al. (2011).

Briefly, we collected fish primarily by nearshore horizontal gillnet (mesh size range: 12-90 $\mathrm{mm}$ ) and supplemented with seining and minnow traps. At pelagic locations, we used vertical gillnets (mesh size range: 12-38 mm). Samples from all species, except Eurasian minnow (Phoxinus phoxinus), consisted of muscle tissue plugs from behind the dorsal fin. Smaller Eurasian minnows were sampled whole and larger ones were skinned and filleted. Collection locations are numbered to correspond with Ahrenstorff et al. (2011), with the exception of sites 7a and 7b, which Ahrenstorff et al. (2011) combined into a single site, 7. 
We collected primary consumers (snails) from the littoral zone by hand at one to seven locations each year to establish the littoral-benthic (periphyton and algae) endmember $\delta^{13} \mathrm{C}$ signature (mean $\mathrm{n}=4$ samples/year, total samples analyzed=20). We removed snails from their shells before analysis. We collected pelagic primary consumers (zooplankton) using a 0.5 -m-diameter $153-\mu \mathrm{m}$-mesh zooplankton net pulled from $50-\mathrm{m}$ deep to the surface in the pelagic zone of the lake at one to three locations each year (mean $\mathrm{n}=2$ samples/year, total samples analyzed=10) (Table 2). Snail samples were sometimes single, large individuals and sometimes as many as six individuals pooled. Zooplankton samples were rinsed and sorted to remove vegetation and debris but not separated by taxonomic group.

\section{Sample analysis}

Samples were dried in a solar oven at $40-80^{\circ} \mathrm{C}$ for one to three days and ground by hand. Stable isotope analysis was conducted at the University of California - Davis (UCD) Stable Isotope Facility on a PDZ Europa 20-20 isotope ratio mass spectrometer for samples from 2006, 2011, 2012 and 2013, and at the University of Washington (UW) IsoLab on a ThermoFinnegan MAT 253 isotope ratio mass spectrometer for samples from 2009. Fourteen replicate samples were analyzed, including two baseline samples, and nine of those samples were additionally analyzed at both UW and UCD. Mean standard error was less than $0.2 \%$ for replicate and less than $0.3 \%$ for triplicate samples for both ${ }^{13} \mathrm{C}$ and $\delta^{15} \mathrm{~N}$. The analytical error (standard deviation of replicate reference material: salmon muscle tissue, bovine liver, glutamic acid, peach leaves) was less than $0.3 \%$ for both $\delta^{13} \mathrm{C}$ and $\delta^{15} \mathrm{~N}$. We excluded four samples from analysis because their high C:N ratio led us to 
suspect the muscle tissue sample had been contaminated or inadequate amounts of tissue were analyzed to obtain reliable estimates for $\delta^{13} \mathrm{C}$ and $\delta^{15} \mathrm{~N}$.

\section{Calculations and corrections}

Isotope results are expressed using delta $(\delta)$ notation: parts per thousand (\%o) from a standard (Vienna PeeDee Belemite for carbon and air for nitrogen) (see Peterson and Fry (1987) for equation).

Lipids have more depleted $\delta^{13} \mathrm{C}$ values than proteins due to enzymatic fractionation in lipid synthesis (DeNiro and Epstein, 1977) and lipid content of muscle can vary widely, making it difficult to compare tissues with different lipid contents. Because lipids contain carbon but not nitrogen, the $\mathrm{C}: \mathrm{N}$ ratio in muscle tissue samples is often used as a proxy for lipid content. Based on Hoffman and Sutton (2010), we assumed that samples with a C:N ratio greater than 3.22 (mass ratio) had increased lipid content and applied a non-linear mass balance correction to the $\delta^{13} \mathrm{C}$ values for those samples:

$$
\delta^{13} \mathrm{C}_{\text {corrected }}=\delta_{13} \mathrm{C}_{\text {uncorrected }}+\frac{\Delta \delta_{13} \mathrm{C}_{\text {lipid }} \times\left(\text { mean } \mathrm{C}: \mathrm{N}_{\text {protein }}-\mathrm{C}: \mathrm{N}_{\text {uncorrected }}\right)}{\mathrm{C}: \mathrm{N}_{\text {uncorrected }}}
$$

where $\Delta \delta_{13} C_{\text {lipid }}$ is the lipid depletion factor, or the difference between the protein and lipid $\delta^{13} \mathrm{C}$ values. Corrected values were calculated using $\Delta \delta_{13} \mathrm{C}_{\text {lipid }}=-6.39 \%$ and mean

C: $\mathrm{N}_{\text {protein }}=3.22$ (converted from 3.76 in molar ratio form to mass ratio form by dividing by 1.667) based on Hoffman and Sutton (2010)'s results (Eq. 6) and comparison to other models (Hoffman et al., 2012; Lake et al., 2001; Logan et al., 2008).

We chose to use a mathematical lipid correction rather than analyze lipid-extracted samples for a number of reasons. Mathematically corrected isotope values have shown 
strong agreement with those from lipid-extracted samples from a wide range of fish taxa (Hoffman and Sutton, 2010; Kiljunen et al., 2006; Logan et al., 2008; Sweeting et al., 2006), and the errors reported in the correction model we used were small $(<0.1 \% 0)$. Although the Hoffman and Sutton (2010) correction was based on deep-sea fish, their results were similar to those from other work (e.g., Logan et al. (2006), Kiljunen et al. (2006)), and we believe that Hoffman and Sutton's (2010) model was well suited to our data because it was based on muscle tissue samples from a large group of species and fitted to a wide range of C:N values.

We used a two end-member mixing model to estimate percent reliance on littoralbenthic prey (namely, the difference between the $\delta^{13} \mathrm{C}$ value of the fish and that of the pelagic baseline over the total difference between the $\delta^{13} \mathrm{C}$ values of the littoral-benthic and pelagic baselines) (Post, 2002; Vander Zanden et al., 2011):

$$
\text { percent benthic }=\frac{\delta^{13} \mathrm{C}_{\text {fish }}-\delta^{13} \mathrm{C}_{\text {pelagic }}}{\delta^{13} \mathrm{C}_{\text {benthiclittoral }}-\delta^{13} \mathrm{C}_{\text {pelagic }}} \times 100
$$

with zooplankton as the pelagic end-member and snails as the benthic end-member. Endmember values were averaged for each year and used to calculate percent littoral-benthic reliance for all the fish collected in that year. We assumed $0 \% 0$ trophic fractionation of carbon.

We calculated trophic level as follows:

$$
\text { trophic level }=\frac{\delta^{15} \mathrm{~N}_{\text {fish }}-\delta^{15} \mathrm{~N}_{\text {baseline }}}{3.4}+2
$$

where the trophic level of a fish is the difference between the $\delta^{15} \mathrm{~N}$ value of the fish and the average of all baseline primary consumers (pelagic and littoral-benthic) for that year, divided by the increment equivalent to a single trophic level (3.4\%o), plus 2 (= the trophic 
level of the primary consumer) (Vander Zanden et al., 1997). We used this simpler model in favor of the two-source model described in Post (2002) because the differences between the trophic positions calculated by each model were negligible.

\section{Data analysis}

Patterns of trophic variability

We expressed variability using coefficient of variation (CV = standard deviation / mean). Calculated $\mathrm{CV}$ values for $\delta^{13} \mathrm{C}$ values were negative (because $\delta^{13} \mathrm{C}$ values are negative and SDs are not) but were converted to absolute values for more intuitive interpretation.

We examined the relationship between isotopic variability and life history and ecological characteristics in a number of ways. We conducted linear regressions on both $\delta^{13} \mathrm{C}$ and $\delta^{15} \mathrm{~N} \mathrm{CV}$, first using littoral-benthic dependence and then trophic level as a predictor. We used Welch's $t$ to test for differences in $\delta^{13} \mathrm{C}$ and $\delta^{15} \mathrm{~N}$ variability between piscivores (burbot, Eurasian perch, lenok) and planktivores (Eurasian minnow, grayling, roach) (Table 1) (Sokal and Braumann, 1980). To determine the relationship between length and $\delta^{13} \mathrm{C}$ and $\delta^{15} \mathrm{~N}$ value, we conducted linear regressions on both $\delta^{13} \mathrm{C}$ and $\delta^{15} \mathrm{~N}$ value and fish total length for all species. We excluded Eurasian minnow from the length analyses because we did not have enough size measurements.

We also used a power analysis to determine the minimum detectable effect size (MDES) over a range of sample sizes given our observed variability. Effect size is directly related to variability and inversely to sample size. As sample size increases, MDES decreases. We used our observed standard deviations in a $t$ test power analysis on both 
$\delta^{13} \mathrm{C}$ and $\delta^{15} \mathrm{~N}$ data for each species over a range of sample sizes, with $\alpha$ (or significance level) $=0.05$ and $\beta$ (or power) $=0.8$ (Murphy and Myors, 2004; Peterman, 1990; Thomas and Juanes, 1996).

Variability across time and space: mixed effects models

We used mixed effects models to assess the effects of year and location on isotopic variability for burbot, Hövsgöl grayling, lenok, Eurasian perch and roach. We excluded Hövsgöl grayling collected by pelagic gillnet from the model because those fish demonstrated distinct $\delta^{13} \mathrm{C}$ values from those collected by littoral gillnet, supporting Ahrenstorff et al.'s (2011) hypothesis that the pelagic and littoral populations are distinct in this lake (K. Olson, unpubl., T. Krabbenhoft, unpubl.).

We considered three mixed effects models that predicted the $\delta^{13} \mathrm{C}$ and $\delta^{15} \mathrm{~N}$ for each species (fit using maximum likelihood with the lme4 package in R (Bates et al., 2013)).

(a) Full model: year + location (+ length)

(b) Year model (without location): year (+ length)

(c) Location model (without year): location (+ length)

We treated both year and sampling location as categorical random intercept effects in all models, because we considered both year and location to be random samples of many possible years or locations, respectively (Bennington and Thayne, 1994; Searle, 1971). We included length as a continuous fixed effect in the models for burbot, Hövsgöl grayling and lenok, but not for perch and roach because we were missing more than a third of length measurements for perch and roach, and regressions on length suggested that length was not a significant factor for $\delta^{15} \mathrm{~N}$ for those two species (Fig. 3). (Note: the models for perch 
and roach were actually random effects models and not mixed effects models because both year and location were both random effects.) To assess the effect of location, we used AIC to compare model (a) and model (b). To assess the effect of year, we compared model (a) and model (c).

Unless specifically noted, we used the R base stats package to conduct statistical analyses (R Core Team, 2013).

\section{Results}

Overview

Fish showed a wide range of $\delta^{13} \mathrm{C}$ values, with burbot relying most heavily on littoral-benthic carbon sources and roach the most reliant on pelagic carbon sources. Perch were the top predators in the system, and Hövsgöl grayling occupied the lowest trophic level. All fish demonstrated $\delta^{15} \mathrm{~N}$ values well within a single trophic level (Table 2, ESM Table S1, Fig. 2).

All species analyzed for length (burbot, Hövsgöl grayling, lenok, perch and roach) showed a highly significant relationship between $\delta^{13} \mathrm{C}$ and total length, with length accounting for $15-43 \%$ of variation. In contrast, only burbot showed a highly (and positive) significant relationship between $\delta^{15} \mathrm{~N}$ value and length $\left(p<0.01, R^{2}=0.55\right)$ (Fig. 3 , Table 3).

Littoral-benthic (snail) and pelagic (zooplankton) baseline $\delta^{13} \mathrm{C}$ values were significantly different (Welch's $t$ test: $t=9.0, \mathrm{df}=27.9, p<0.01$ ). Littoral-benthic baseline $\delta^{15} \mathrm{~N}$ values were similar to those of the pelagic baseline samples over all four sampling years (Welch's $t$ test: $t=0.9, \mathrm{df}=23.6, p=0.37$ ) (Fig. 2, Table 2). Neither $\delta^{13} \mathrm{C}$ nor $\delta^{15} \mathrm{~N}$ littoral- 
benthic baseline values varied significantly by location $\left(\delta^{13} \mathrm{C}\right.$ ANOVA: $F(7,12)=0.2, p=0.89$; $\delta^{15} \mathrm{~N}$ ANOVA: $\left.F(7,11)=1.5, p=0.27\right)$.

\section{Patterns of trophic variability}

Variability in $\delta^{13} \mathrm{C}$ was negatively and significantly correlated with littoral-benthic dependence, with littoral-benthic species (e.g., burbot) demonstrating lower variability in all years than pelagic species (e.g. roach) (linear regression of $\delta^{13} \mathrm{C} \mathrm{CV}$ on littoral-benthic dependency; $R^{2}=0.21$, p < 0.01, Fig. 1, ESM Fig. 2). Variability in $\delta^{13} \mathrm{C}$ showed no relationship, however, with trophic level or trophic guild. Variability in $\delta^{15} \mathrm{~N}$ showed no relationship with littoral-benthic dependence, trophic level or feeding category.

\section{Variability across time and space}

Interannual $\delta^{13} \mathrm{C}$ variability for any given species, as indicated by $\delta^{13} \mathrm{C} \mathrm{CV}$, ranged from substantially less than 0.1 for many species in many years to 0.2 (lenok, 2009, n=17). Within-location variability in $\delta^{13} \mathrm{C}$ was similar, ranging from less than 0.1 (Eurasian minnow, location $7 \mathrm{a}, \mathrm{n}=3$ ) to 0.2 (roach, location $3, \mathrm{n}=3$ ). The range in $\delta^{15} \mathrm{~N}$ variability was similar to that of $\delta^{13} \mathrm{C}$, with CV values ranging from less than 0.1 (Eurasian minnow, 2012, $\mathrm{n}=4$ ) to 0.2 (lenok, 2006, $\mathrm{n}=9$ ) by year and from less than 0.1 (Eurasian minnow, location 9 , $\mathrm{n}=2$ ) to 0.2 (lenok, location $8, \mathrm{n}=13$ ) by location (ESM Table S1).

The mixed (and random) effects models suggested that while both collection year and location had significant effects on $\delta^{13} \mathrm{C}$ and $\delta^{15} \mathrm{~N}$ variability for some species, location had a significant effect for more species than did year on both $\delta^{13} \mathrm{C}$ and $\delta^{15} \mathrm{~N}$ variability. Based on AIC values, the year models without location as a predictor were a poorer fit than 
the full model for all species except lenok for $\delta^{13} \mathrm{C}$, and for both perch and roach for $\delta^{15} \mathrm{~N}$, suggesting a significant effect of location in all of those cases. In contrast, the location models without year as a predictor were a poorer fit only for roach (for $\delta^{13} \mathrm{C}$ ) and for lenok (for $\delta^{15} \mathrm{~N}$ ), suggesting a significant effect of year only in those cases (Table 3).

The MDES (minimum detectable effect size) for $\delta^{13} \mathrm{C}$ at $\mathrm{n}=10$ was smallest for burbot $(1.2 \%)$, the species with the smallest $\delta^{13} \mathrm{C}$ variance, and largest for roach $(4.6 \%)$, the species with the greatest variance. The MDES for $\delta^{15} \mathrm{~N}$ at $\mathrm{n}=10$ ranged from $0.9 \%$ for Hövsgöl grayling to $1.3 \%$ o for Eurasian minnow. The MDES shrank considerably for all species between $n=5$ and $n=20$, especially for species with high variability, such as roach for $\delta^{13} \mathrm{C}$ and Eurasian minnow for $\delta^{15} \mathrm{~N}$. The MDES continued to decrease gradually for all species until $n \sim 100$, beyond which increased sample size had limited effect (ESM Fig. S1).

\section{Discussion}

The food web in this simple, near-pristine system demonstrated a host of interesting features, including a high degree of trophic level overlap. Variability in $\delta^{13} \mathrm{C}$ in fish in this system was inversely related to littoral-benthic dependence. Space and time both appeared to have significant effects on isotopic variability, with space having a slightly greater effect than time. The observed variability in this system was higher than that reported in other large, oligotrophic lakes (Harvey and Kitchell, 2000; Vander Zanden et al., 2003; Yoshii, 1999) comparable to that attributed in other systems to the introduction of non-native species (Schmidt et al., 2009; Vander Zanden et al., 1999), but less than that ascribed to eutrophication and nitrogen loading (Cabana and Rasmussen, 1996; Lake et al., 2001). 
Trophic level overlap and omnivory

Lake Hövsgöl's food web was characterized by a high degree of trophic level overlap. The difference in mean trophic level between the lowest (Hövsgöl grayling) and highest (perch) trophic level species consumers was only 0.8 (Table 2). This trophic overlap suggests that many of the fish in the system are consuming prey on similar trophic levels, and, in particular, that piscivorous fish in this system are likely engaging in vertical omnivory (sensu Vadeboncoeur et al., 2005) and consuming some quantity of lowertrophic level prey in addition to fish. These results corroborate the diet habits documented in this system: Sideleva (2006) and Ahrenstorff (2011) reported that a wide range of invertebrates figured prominently in the diets of all fish species in the lake. Chandra et al. (2005a) also reported generalist diets in lenok and Baikal grayling in downstream tributaries. This degree of trophic level overlap falls within the range reported in other oligotrophic lakes (for example, mean trophic level range for Arctic lakes: 0.4 (Sierszen et al., 2003), Lake Superior: 1.2 (Schmidt et al., 2009), Lake Winnipeg: 0.59 in South Basin and 1.78 over entire lake (Hobson et al., 2012)).

$\underline{\delta^{13} \mathrm{C} \text { variability and littoral-benthic dependence }}$

Species that demonstrated greater dependence on pelagic pathways, such as perch and roach, displayed significantly greater $\delta^{13} \mathrm{C}$ variability than species that demonstrated greater dependence on littoral-benthic pathways, such as burbot (Fig. 1, ESM Fig. S2). This pattern can be at least in part attributed to interspecies differences in ontogenetic habitat and diet shifts. The four species with more pelagic $\delta^{13} \mathrm{C}$ values (roach, Eurasian perch, 
lenok and Hövsgöl grayling) demonstrated a significant increase in $\delta^{13} \mathrm{C}$ (from more pelagic to more littoral-benthic values) with increasing fish length (Fig. 3). These ontogenetic shifts are likely mediated by a host of competitive and predator-prey interactions. A number of studies have documented ontogenetic diet shifts in perch from zooplankton, to benthic invertebrates, and then to fish, especially in the presence of roach (Amundsen et al., 2003; Persson, 1986; Persson and Greenberg, 1990). Roach are known to be more efficient zooplankton feeders than perch are, and therefore effective competitors with perch for zooplankton (Persson, 1987), which may encourage perch to feed on other (more benthic) prey. The shift from pelagic to littoral-benthic resources in perch with increasing size here may be mediated by similar perch-roach competitive interactions. Ahrenstorff et al. (2011) observed a similar ontogenetic diet shift in Hövsgöl grayling from zooplankton to benthic invertebrates with increasing length and hypothesized that this pattern is likely a result of juvenile grayling seeking out the pelagic zone as a predation refuge and then moving to forage inshore as they grow larger and less vulnerable to predation (as described by Werner and Hall (1988) for bluegill). Ahrenstorff et al. (2011) also found intermediatesized Hövsöl grayling in both pelagic and littoral zones of the lake (and substantially different diets between fish of the same size found it different habitats), suggesting variability in behavior which likely contributes to the isotopic variability we observed. Tradeoffs between predator refugia and foraging efficiency may also explain some of the wide range of $\delta^{13} \mathrm{C}$ values in roach; in the presence of predatory perch, roach have been shown to alternate between littoral habitats (which provide better refuge) and pelagic habitats (which provide superior zooplankton foraging) (Eklöv and VanKooten, 2001; Persson and Eklov, 1995). 
In contrast to these species, burbot - the species with the most enriched $\delta^{13} \mathrm{C}$ values and lowest $\delta^{13} \mathrm{C}$ variability (Fig. 2, Table 2, ESM Fig. S2) - demonstrated a significant decrease, rather than an increase, in $\delta^{13} \mathrm{C}$ with increasing size (Fig. 3). Burbot have been shown to undergo ontogenetic diet shifts from benthic invertebrates (with enriched $\delta^{13} \mathrm{C}$ values) to fish (with more intermediate or depleted $\delta^{13} \mathrm{C}$ values, especially in smaller individuals) (Amundsen et al., 2003), which could in part explain this pattern. The significant and substantial increase we observed in $\delta^{15} \mathrm{~N}$ in larger burbot, further corroborates such an ontogenetic shift in Lake Hövsgöl burbot.

This high degree of $\delta^{13} \mathrm{C}$ variability in pelagic species - suggesting a substantial littoral-benthic contribution even to pelagic foragers - contributes to the extensive body of literature emphasizing the importance of benthic and littoral primary production to overall lake productivity (Hecky and Hesslein, 1995; Schindler and Scheuerell, 2002; Vander Zanden and Vadeboncoeur, 2002), even in large, deep lakes (Hampton et al., 2011; Vadeboncoeur et al., 2011; Vander Zanden et al., 2011), and especially in highly oligotrophic lakes (Loeb et al., 1983; McIntyre et al., 2006; Sierszen et al., 2003), but adds yet another twist. Previous work has focused on piscivorous fish as critical links between littoral-benthic and pelagic food webs; in this system it is not just piscivorous, but also fish species at lower trophic levels, that appear to be linking the two food webs. Our results reinforce Bertolo's (2005) argument that the "paradigm of piscivorous fish as integrators of pelagic and littoral food webs...needs to integrate the role of functional fish diversity to fully explain the food-web dynamics in oligotrophic systems."

It is worth noting that this relationship between $\delta^{13} \mathrm{C}$ variability and littoral-benthic dependence is discernable only because we are examining isotopic variability as well as 
isotopic values. Mean values alone would not have uncovered this pattern; we suggest that analysis of isotopic variability may be a useful addition to future trophic ecology studies.

We also point out that the differences in isotopic variability among the species we studied here substantially affect sample sizes required to detect a given degree of isotopic change. For example, in order to detect a difference of $4 \%$ (half the distance between our pelagic and littoral-benthic baselines) with a $t$ test, a sample size of $\mathrm{n}<5$ in each group would suffice for a low-variability species such as burbot, but a high-variability species such as roach would require $n>12$ in each group. Determination of sample size is best informed by the degree of variability in isotopic values anticipated in the study population.

\section{Variability across time and space}

A central question for this study is whether time or space had a greater influence on isotopic variability in this system. Work across other systems has found that spatial variability exceeds temporal variability - though primarily using measures other than stable isotope values. Some examples of this work include Kratz's $(2003 ; 1995)$ analyses of a wide range of metrics across twelve LTER sites and Roset's (2007) review of indices of biotic integrity. Our results support this trend; on the whole in this system, space had a bigger impact than time on isotopic variability, and that impact was seen more strongly on $\delta^{13} \mathrm{C}$ variability than on $\delta^{15} \mathrm{~N}$ variability (Table 3 ).

We expected that we might see some spatial variability correlated with land use. For example, we suspected that individuals found in locations with more human settlement or grazing might have elevated $\delta^{15} \mathrm{~N}$ ratios because nitrate from animal waste tends to be enriched compared to nitrate from other sources (Hoffman et al., 2012; Kendall et al., 
2007). We did not, however, see elevated $\delta^{15} \mathrm{~N}$ in fish or in littoral-benthic baseline samples from locations with human settlement or grazing (locations 2, 6, 9) compared with those from forested or wetland locations with no grazing or settlement (locations $3,7 \mathrm{a}, 7 \mathrm{~b}$, 8).

An important factor to consider in our assessment of isotopic differences across space is potential temporal and spatial variability in our baseline samples. Values of $\delta^{13} \mathrm{C}$ and $\delta^{15} \mathrm{~N}$ baselines are known to vary across both time and space (Graham et al., 2009). Solomon (2008) showed significant changes in both $\delta^{13} \mathrm{C}$ and $\delta^{15} \mathrm{~N}$ baselines over time, and Hobson et al. (2012) showed a clear spatial pattern - or isoscape - in $\delta^{13} \mathrm{C}$ of dissolved organic carbon and $\delta^{15} \mathrm{~N}$ of nitrate in Lake Winnipeg which were reflected in the isotopic values of the fish collected at different locations in the lake. We did not collect separate baseline samples at each location, so it is possible that the spatial variability we detected in fish may actually have been a function of undetected variability in baseline values. We did not, however, see significant differences between locations or between years in $\delta^{13} \mathrm{C}$ or $\delta^{15} \mathrm{~N}$ in the baseline samples we did collect, so we suspect that the temporal and spatial variability we observed reflected variability in fish diets rather than differences in baseline values.

Our analysis also captured only horizontal, and not vertical (or depth-related), variability in this system. Benthic organisms and their fish predators in other oligotrophic lakes have been shown to demonstrate increasing $\delta^{15} \mathrm{~N}$ and decreasing $\delta^{13} \mathrm{C}$ values with increasing depth (Sierszen et al., 2014; 2006; Yoshii, 1999), likely due to a shift in diet from primarily benthic algae in the littoral zone to more phytoplankton in deeper water (Sierszen et al., 2006) and/or less discriminant fractionation of carbon in shallow water 
(characterized by high light, high photosynthetic rates and a carbon-depleted boundary layer) than in deeper water (Cummings and Schindler, 2013). We collected our littoralbenthic baseline (snails) only in the littoral zone, so our littoral-benthic baseline signature did not capture any depth gradient. Such depth-related isotopic variability is almost certainly relevant to fish in Lake Hövsgöl. Hövsgöl grayling (Ahrenstorff et al., 2011) in this system and burbot (Harrison et al., 2013) and perch (Eckmann and Imbrock, 1996) in other systems have all demonstrated diel vertical migration patterns. Our use of only littoral benthic baseline samples to calculate trophic position may have resulted in slightly elevated estimates of trophic level for those species.

Our sampling regime also did not capture any seasonal variability in fish diets, which is reported in Sideleva (2006). The values we report likely reflect integrated diet from late spring through early summer. Fish have been shown to integrate isotopes into muscle tissue over a scale of weeks to months (Buchheister and Latour, 2010; Weidel et al., 2011), and food consumed in winter months (a time of little somatic growth) is generally not reflected in muscle isotopic values (Perga and Gerdeaux, 2005).

These results suggest that in Lake Hövsgöl, and perhaps other large lakes, sampling must be both spatially and temporally extensive to capture the full range of isotopic variability, as work has suggested in other systems (Kratz et al., 1995; Roset et al., 2007). If one has to choose, however, sampling at multiple locations may be more illuminative than sampling in multiple years. Furthermore, space-for-time substitutions must be conducted with care (Kratz et al., 2003).

\section{Variability in other systems}


The interannual intraspecies variability that we observed in Lake Hövsgöl was higher than that reported in other large oligotrophic lakes for both $\delta^{13} \mathrm{C}$ and $\delta^{15} \mathrm{~N}$. In Lake Baikal, Hövsgöl's giant and ancient near neighbor, Yoshii et al. (1999) found much lower variability in $\delta^{13} \mathrm{C}$ and $\delta^{15} \mathrm{~N}$ in five species of fish. In Lake Tahoe, which is smaller in volume but much deeper than Lake Hövsgöl, Vander Zanden et al. (2003) also found lower $\delta^{13} \mathrm{C}$ and $\delta^{15} \mathrm{~N}$ variability. And in Lake Superior, which is much larger and deeper than Hövsgöl, though with a longer history of fishing, development and invasive species, Harvey and Kitchell (2000) found lower $\delta^{13} \mathrm{C}$ and $\delta^{15} \mathrm{~N}$ variability in eleven species of fish (ESM Table S2a-c).

These differences in variability cannot be attributed to temporal and/or spatial scopes of sampling, which occurred over a range of scales in these studies. Harvey and Kitchell (2000) sampled only in the western arm of the lake for only two sampling years. However, the Lake Baikal study (Yoshii et al., 1999) sampled more than 30 locations throughout the lake (as well as from commercial fishermen) over three years. We expected that larger lakes - with more area for habitats, refuges, subpopulations and environmental conditions - might demonstrate greater variability than smaller lakes. However, lake size did not appear to have a definitive impact on isotopic variability, because both Lake Baikal (Yoshii et al., 1999) (much larger than Hövsgöl) and Lake Tahoe (Vander Zanden et al., 2003) (smaller than Hövsgöl) exhibited much lower variability than did Hövsgöl (ESM Table S2a-c).

We suspected that Lake Hövsgöl's relative ecological youth compared to other systems might also be a factor in its demonstrated variability; with less time for evolution and specialization, younger lakes are more likely than older lakes to contain low-diversity 
fish communities comprised of generalists (Doi et al., 2012). And indeed, Lake Baikal, the oldest lake in the world (27.5 million years) (Doi et al., 2012), demonstrated extremely low $\delta^{13} \mathrm{C}$ and $\delta^{15} \mathrm{~N}$ variability (Yoshii et al., 1999), and some other younger lakes, such as Lake Washington (13,000 years) (Edmondson, 1994) demonstrated higher $\delta^{13} \mathrm{C}$ and $\delta^{15} \mathrm{~N}$ variability (McIntyre et al., 2006), similar to that of Hövsgöl. But Lake Superior, similar in age to Hövgöl (9000 years) (Doi et al., 2012), as mentioned above, demonstrated low $\delta^{13} \mathrm{C}$ and $\delta^{15} \mathrm{~N}$ variability, and other old lakes, such as Lake Malawi (10 million years) and Lake Albert (4 million years) (Doi et al., 2012) demonstrated $\delta^{13} \mathrm{C}$ and $\delta^{15} \mathrm{~N}$ variability comparable or higher to that in Lake Hövsgöl (Campbell et al., 2005; Kidd et al., 2004), suggesting that the degree of variability observed in this lake also cannot be attributed primarily to age (ESM Table S2a).

The trophic variability we observed also does not appear to be correlated with disturbance level. "Disturbance" is challenging to assess, but other lakes subject to greater disturbance than Lake Hövsgöl by any measure (nearby urban development, heavy fishing pressure, or number of introduced species) demonstrated both comparable and lower variability than Lake Hövsgöl. Observed $\delta^{13} \mathrm{C}$ and $\delta^{15} \mathrm{~N}$ variability in Lake Washington, in downtown Seattle (McIntyre et al., 2006), was similar to that in Lake Hövsgöl. But observed $\delta^{13} \mathrm{C}$ and $\delta^{15} \mathrm{~N}$ variability was lower than that in Lake Hövsgöl in many other lakes subject to more human impacts than Lake Hövsgöl, including Lake Erie (Guzzo et al., 2011), and Lake Ontario (Kiriluk et al., 1995) (both prone to algal blooms and invaded by zebra mussels) as well as Lake Superior (Harvey and Kitchell, 2000) and Lake Baikal (Yoshii et al., 1999) (both with low nutrient loading but subject to commercial fishing) (ESM Table 3). In the end, Lake Hövsgöl's high isotopic variability may be the result of a combination of a 
range of factors: ecological youth, paucity of species, relative size and low level of disturbance.

Isotopic shifts attributable to specific anthropogenic changes

One of the goals of this study was to provide context for isotopic shifts attributed in other systems to specific anthropogenic changes, not just overall level of disturbance. Interestingly, if we compare mean $\delta^{13} \mathrm{C}$ and $\delta^{15} \mathrm{~N}$ values observed in Lake Hövsgöl between years, the differences are comparable to or greater than shifts in other systems associated with introduced or invasive species. For example, the difference in mean $\delta^{13} \mathrm{C}$ and $\delta^{15} \mathrm{~N}$ in lake trout documented by Vander Zanden et al. (1999) in North American lakes with and without invasive bass was well within the range of the interannual and between-site differences in means that we observed in Lake Hövsgöl (ESM Table S3). The shift in $\delta^{15} \mathrm{~N}$ in lake trout in Lake Superior in the early part of the $20^{\text {th }}$ century (Schmidt et al., 2009), a time period that included the introduction of sea lamprey, was also comparable to (or slightly higher than) variability in $\delta^{15} \mathrm{~N}$ we observed in Lake Hövsgöl (ESM Table S3).

In contrast, isotopic shifts in other systems attributed to cultural eutrophication and anthropogenic nitrogen loading were substantially larger than any interannual or spatial shifts we observed in Lake Hövsgöl. Cabana and Rasmussen (1996) reported a range of $\sim 11.5 \%$ in $\delta^{15} \mathrm{~N}$ values in primary producers across a gradient of human population density, and Lake (2001) reported ranges of $\sim 5-6 \%{ }_{0} \delta^{15} \mathrm{~N}$ in yellow perch and smallmouth bass along a gradient of increasing residential land use.

We do not mean to imply that the reported differences cited in these studies are a function of natural variability rather than the anthropogenic changes with which they were 
correlated; the differences in all cases were clearly highly significant. Our results do suggest, however, that many other changes in food webs - especially those that are biologically, as opposed to chemically, mediated - may be obscured or swamped by the scale of natural variability.

This study also suggests that the range of "natural" variability can be quite high even in the absence of major anthropogenic impacts. In addition, these results suggest that the absence of fishing may not always be correlated with lower variability (or increased stability). Hsieh et al. (2006) and Anderson et al. (2008)'s work demonstrated increased population variability (and reduced stability) associated with fishing as the result of truncation of population age structure. While we were looking at isotopic rather than population variability, population variability is likely to be associated with food web changes, and our results suggest that high variability may occur even in a system with little or no fishing.

We note that Lake Hövsgöl is not an entirely "pristine" system; as discussed above, there is some development and grazing, especially in the southwest region of the lake, and preliminary data suggest limited poaching using nearshore gillnets (C. Free, unpubl.). Lake Hovsgol also has higher levels of microplastic pollution than some of the Laurentian Great Lakes (Free et al., 2014). We feel confident, however, that both the degree of development and the level of fishing are significantly lower than in comparable systems.

\section{Conclusions}


The isotopic food web of Lake Hövsgöl demonstrated extensive trophic level overlap and an inverse relationship between $\delta^{13} \mathrm{C}$ variability and littoral-benthic dependence. The latter pattern can be attributed to interspecies differences in ontogenetic diet shifts.

Isotopic values in this system varied more over space than time. The interannual isotopic variability observed in Lake Hövsgöl was greater than natural variability reported in other systems, similar to variability attributed in other systems to introductions of nonnative species, and less than variability attributed to anthropogenic chemical change such as eutrophication. This scale of natural variability may obscure many changes in food webs, anthropogenically mediated or otherwise. These data on the spatial and temporal extent of isotopic variability in this near-pristine lake complement studies on isotopic variability in other lakes discussed in the introduction (Guzzo et al., 2011; Harvey and Kitchell, 2000; Hobson et al., 2012; Mbabazi et al., 2010; Syväranta et al., 2006), as well as the extensive body of work on spatial and temporal variability in fish and zooplankton abundance and community composition in a wide range of North American lakes (Brind'Amour et al., 2005; Kratz et al., 1987; Magnuson et al., 1994; Olden et al., 2006; Rusak et al., 2002).

\section{Acknowledgments}

This project was funded by a National Science Foundation grant (NSF OISE: 1064843) to 0 Jensen, the Trust for Mutual Understanding and the Waitt Foundation. T Young was supported by a Graduate Research Fellowship from the National Science Foundation (NSF DGE: 0937373). We are grateful to the Taimen Conservation Fund, the Mongol Ecology Center and our Mongolian-American research team, including M Amaraa, N Bagdal, 
G Byford, Boidkhand, Boloroo, H Chantuu, L Chuluunchimeg, H DeBey, C Free, B Ganzorig, D Gilroy, A Hermes, T Hrabik, M Hickman, F Ianucci, G Jargalmaa, M Kessler, T and C Krabbenhoft, A Lahr, B Mendsaikhan, N McAuliffe, E McGinley, N Mercado-Silva, G Natsag, U Nemekhbayar, K Olson, M Provost, I Roman, J Waldman, and T Zimmerman. We thank the Jensen lab group at Rutgers, J Hoffman, and M Sierszen, M Vinson and an anonymous reviewer for manuscript comments. Reference to trade names does not imply endorsement by the U.S. government. This article is Contribution [number not yet designated] of the USGS Great Lakes Science Center. 


\section{References}

Ahrenstorff, T.D., Jensen, O.P., Weidel, B.C., Mendsaikhan, B., Hrabik, T.R., 2011. Abundance, spatial distribution, and diet of endangered Hovsgol grayling (Thymallus nigrescens). Environ Biol Fish 94, 465-476.

Amundsen, P., Bøhn, T., Popova, O., Staldvik, F., Reshetnikov, Y., Kashulin, N., Lukin, A., 2003. Ontogenetic niche shifts and resource partitioning in a subarctic piscivore fish guild. Hydrobiologia 497, 109-119.

Anderson, C.N.K., Hsieh, C.-H., Sandin, S.A., Hewitt, R., Hollowed, A., Beddington, J.R., Sugihara, G., May, R.M., 2008. Why fishing magnifies fluctuations in fish abundance. Nature 452, 835-839.

Bates, D., Maechler, M., Bolker, B., Walker, S., 2013. lme4: Linear mixed-effects models using Eigen and S4.

Batschelet, E., 1981. Circular Statistics. Academic Press, New York.

Bennington, C., Thayne, W., 1994. Use and misuse of mixed model analysis of variance in ecological studies. Ecology 717-722.

Berg, L.S., 1962. Freshwater Fishes of the U.S.S.R. and Adjacent Countries. Israel Program for Scientific Translations for the National Science Foundation, Jerusalem.

Bertolo, A., Carignan, R., Magnan, P., Pinel Alloul, B., Planas, D., Garcia, E., 2005. Decoupling of pelagic and littoral food webs in oligotrophic Canadian Shield lakes. Oikos 111, 534-546.

Brind'Amour, A., Boisclair, D., Legendre, P., Borcard, D., 2005. Multiscale spatial distribution of a littoral fish community in relation to environmental variables. Limnol Oceanogr 50, 465-479.

Buchheister, A., Latour, R.J., 2010. Turnover and fractionation of carbon and nitrogen stable isotopes in tissues of a migratory coastal predator, summer flounder (Paralichthys dentatus). Can J Fish Aquat Sci 67, 445-461.

Cabana, G., Rasmussen, J.B., 1996. Comparison of aquatic food chains using nitrogen isotopes. Proc Natl Acad Sci USA 93, $10844-10847$.

Campbell, L.M., Wandera, S.B., Thacker, R.J., Dixon, D.G., Hecky, R.E., 2005. Trophic niche segregation in the Nilotic ichthyofauna of Lake Albert (Uganda, Africa). Environ Biol Fish 74, 247-260.

Carpenter, S.R., Brock, W.A., 2006. Rising variance: a leading indicator of ecological transition. Ecol Lett 9, 311-318.

Carpenter, S.R., Cole, J., Pace, M., Batt, R., Brock, W.A., Cline, T., Coloso, J., Hodgson, J., Kitchell, J.F., Seekell, D., 2011. Early warnings of regime shifts: a whole-ecosystem experiment. Science 332, 1079-1082.

Chandra, S., Gilroy, D.J., Purevdorj, S., Erdenebat, M., 2005a. The feeding behaviour of fish from the upper Lake Baikal watershed of the Eroo River in Mongolia. Mong J Biol Sci 3, 39-45.

Chandra, S., Vander Zanden, M.J., Heyvaert, A., Richards, B., Allen, B.C., Goldman, C., 2005b. The effects of cultural eutrophication on the coupling between pelagic primary producers and benthic consumers. Limnol Oceanogr 1368-1376.

Cummings, B.M., Schindler, D.E., 2013. Depth variation in isotopic composition of benthic resources and assessment of sculpin feeding patterns in an oligotrophic Alaskan lake. Aquat Ecol 47, 403-414.

Dagvadorj, D., Natsagdorj, L., Dorjpurev, J., Namkhainyam, B., 2009. Mongolia: Assessment Report on Climate Change 2009. Ministry of Environment, Nature and Tourism, Mongolia.

Dakos, V., Beninca, E., Van Nes, E.H., Philippart, C.J.M., Scheffer, M., Huisman, J., 2009. Interannual variability in species composition explained as seasonally entrained chaos. Proc R Soc B 276, 2871-2880.

DeNiro, M., Epstein, S., 1977. Mechanism of carbon isotope fractionation associated with lipid synthesis. Science 197, 261-263. 
Doi, H., Vander Zanden, M.J., Hillebrand, H., 2012. Shorter food chain length in ancient lakes: evidence from a global synthesis. PLoS ONE 7 , e37856.

Dulmaa, A., 1999. Fish and Fisheries in Mongolia, in: Petr, T. (Ed.), Fish and Fisheries at Higher Altitudes: Asia. FAO - Food and Agriculture Organization of the United Nations, Rome.

Eckmann, R., Imbrock, F., 1996. Distribution and diel vertical migration of Eurasian perch (Perca fluviatilis L.) during winter. Ann Zool Fennici $33,679-686$.

Edmondson, W., 1994. Sixty years of Lake Washington: a curriculum vitae. Lake Reserve. Manage. 10, 75-84.

Eklöv, P., VanKooten, T., 2001. Facilitation among piscivorous predators: effects of prey habitat use. Ecology 82, 2486-2494.

Fratt, T.W., Coble, D.W., Copes, F., Bruesewitz, R.E., 2001. Diet of burbot in Green Bay and western Lake Michigan with comparison to other waters. J Great Lakes Res 23, 1-10.

Free, C.M., Jensen, O.P., Mason, S.A., Eriksen, M., Williamson, N.J., Boldgiv, B., 2014. High-levels of microplastic pollution in a large, remote, mountain lake. Mar Pollut Bull 85, 156-163.

Frost, W., 1943. The natural history of the minnow, Phoxinus phoxinus. J Anim Ecol 139-162.

Goulden, C.E., Boldgiv, B., 2002. Lake Hövsgöl, Mongolia: the blue pearl of Mongolia. SIL News 36, 1-4.

Goulden, C.E., Tumurtogoo, O., Karabanov, E., Mongontsetseg, A., 2006. Chapter 1: The geological history and geography of Lake Hövsgöl, in: Goulden, C.E., Sitnikov, T., Gelhaus, J., Boldgiv, B. (Eds.), The Geology, Biodiversity and Ecology of Lake Hövsgöl. Backhuys Publishers, Leiden, the Netherlands, pp. 1-19.

Graham, B.S., Koch, P.L., Newsome, S.D., McMahon, K.W., Aurioles, D., 2009. Using Isoscapes to Trace the Movements and Foraging Behavior of Top Predators in Oceanic Ecosystems, in:. Springer Netherlands, Dordrecht, pp. 299-318.

Guzzo, M.M., Haffner, G.D., Sorge, S., Rush, S.A., Fisk, A.T., 2011. Spatial and temporal variabilities of $\delta^{13} \mathrm{C}$ and $\delta^{15} \mathrm{~N}$ within lower trophic levels of a large lake: implications for estimating trophic relationships of consumers. Hydrobiologia 675, 41-53.

Hampton, S.E., Fradkin, S., Leavitt, P., Rosenberger, E., 2011. Disproportionate importance of nearshore habitat for the food web of a deep oligotrophic lake. Mar Freshwater Res 62, 350-358.

Harrison, P.M., Gutowsky, L., Martins, E.G., Patterson, D.A., Leake, A., Cooke, S.J., Power, M., Tierney, K., 2013. Diel vertical migration of adult burbot: a dynamic trade-off among feeding opportunity, predation avoidance, and bioenergetic gain. J Fish Res Board Can 70, 17651774.

Harvey, C., Kitchell, J.F., 2000. A stable isotope evaluation of the structure and spatial heterogeneity of a Lake Superior food web. Can J Fish Aquat Sci 57, 1395-1403.

Hecky, R.E., Hesslein, R., 1995. Contributions of benthic algae to lake food webs as revealed by stable isotope analysis. J N Am Benthol Soc 14, $631-653$.

Herdendorf, C., 1982. Large lakes of the world. J Great Lakes Res 8, 379-412.

Hobson, K.A., Ofukany, A., Soto, D.X., Wassenaar, L.I., 2012. An isotopic baseline $\left(\delta^{13} \mathrm{C}, \delta^{15} \mathrm{~N}\right)$ for fishes of Lake Winnipeg: Implications for investigating impacts of eutrophication and invasive species. J Great Lakes Res 38, 58-65.

Hoffman, J.C., Kelly, J.R., Peterson, G.S., Cotter, A.M., Starry, M.A., Sierszen, M.E., 2012. Using $\delta^{15} \mathrm{~N}$ in fish larvae as an indicator of watershed sources of anthropogenic nitrogen: response at multiple spatial scales. Estuar Coasts 35, 1453-1467. 
Hoffman, J.C., Sutton, T.T., 2010. Lipid correction for carbon stable isotope analysis of deep-sea fishes. Deep-Sea Res Pt I 57, $956-964$.

Hsieh, C.-H., Reiss, C.S., Hunter, J.R., Beddington, J.R., May, R.M., Sugihara, G., 2006. Fishing elevates variability in the abundance of exploited species. Nature 443, 859-862.

Jacobs, G.R., Madenjian, C.P., Bunnell, D.B., Holuszko, J.D., 2010. Diet of lake trout and burbot in Northern Lake Michigan during spring: Evidence of ecological interaction. J Great Lakes Res 36, 312-317.

Karabanov, E., Williams, D., Kuzmin, M.I., Sideleva, V.G., Khursevich, G., Prokopenko, A.A., Solotchina, E., Tkachenko, L., Fedenya, S., Kerber, E., 2004. Ecological collapse of Lake Baikal and Lake Hovsgol ecosystems during the Last Glacial and consequences for aquatic species diversity. Palaeogeogr Palaeoclimatol Palaeoecol 209, 227-243.

Kendall, C., Elliott, E.M., Wankel, S.D., 2007. Chapter 12: Tracing anthropogenic inputs of nitrogen to ecosystems, in: Michener, R., Lajtha, K. (Eds.), Stable Isotopes in Ecology and Environmental Science. Blackwell Scientific Publications, Malden, MA, pp. 375-449.

Kidd, K.A., Bootsma, H.A., Hesslein, R.H., Lockhart, W.L., Hecky, R.E., 2004. Mercury concentrations in the food web of Lake Malawi, East Africa. J Great Lakes Res 29, 258-266.

Kiljunen, M., Grey, J., Sinisalo, T., Harrod, C., Immonen, H., Jones, R.I., 2006. A revised model for lipid-normalizing $\delta 13 \mathrm{C}$ values from aquatic organisms, with implications for isotope mixing models. J Appl Ecol 43, 1213-1222.

Kiriluk, R., Servos, M., Whittle, D., Cabana, G., Rasmussen, J., 1995. Using ratios of stable nitrogen and carbon isotopes to characterize the biomagnification of DDE, mirex, and PCB in a Lake Ontario pelagic food web. Can J Fish Aquat Sci 52, 2660-2674.

Kozhova, O.M., Kobanova, G.I., 2006. Chapter 10: Phytoplankton of Lake Hovsgol, in: Goulden, C.E., Sitnikov, T., Gelhaus, J., Boldgiv, B. (Eds.), The Geology, Biodiversity and Ecology of Lake Hövsgöl. Backhuys Publishers, Leiden, the Netherlands, pp. 135-143.

Kratz, T., Deegan, L., Harmon, M., Lauenroth, W., 2003. Ecological variability in space and time: Insights gained from the US LTER program. BioScience 53, 57-67.

Kratz, T., Frost, T., Magnuson, J., 1987. Inferences from spatial and temporal variability in ecosystems: long-term zooplankton data from lakes. Am Nat 830-846.

Kratz, T., Magnuson, J., Bayley, P., Benson, B., Berish, C., Bledsoe, C., Blood, E., Bowser, C., Carpenter, S., Cunningham, G., 1995. Temporal and spatial variability as neglected ecosystem properties: Lessons learned from 12 North American ecosystems, in: Rapport, D.J., Gaudet, C.L., Calow, P. (Eds.), Evaluating and Monitoring the Health of Large-Scale Ecosystems. Springer Berlin Heidelberg, Berlin, pp. 359-383.

Lake, J.L., McKinney, R.A., Osterman, F.A., Pruell, R.J., Kiddon, J., Ryba, S.A., Libby, A.D., 2001. Stable nitrogen isotopes as indicators of anthropogenic activities in small freshwater systems. Can J Fish Aquat Sci 58, 870-878.

Landres, P., Morgan, P., Swanson, F., 1999. Overview of the use of natural variability concepts in managing ecological systems. Ecol Appl 9 , $1179-1188$.

Loeb, S., Reuter, J., Goldman, C., 1983. Littoral zone production of oligotrophic lakes, in: Wetzel, R.G. (Ed.), Periphyton of Freshwater Ecosystems. pp. 161-167.

Logan, J.M., Jardine, T.D., Miller, T.J., Bunn, S.E., Cunjak, R.A., Lutcavage, M.E., 2008. Lipid corrections in carbon and nitrogen stable isotope analyses: comparison of chemical extraction and modelling methods. J Anim Ecol 77, 838-846.

Magnuson, J., Benson, B., McLain, A., 1994. Insights on species richness and turnover from long-term ecological research: fishes in north temperate lakes. Am Zool 34, 437-451. 
Manchin, E., Dgebuadze, Y., 2010. Alien fish species within Mongolian part of the Selenga River basin. Russ J Biol Invasions 1, $227-231$.

Mbabazi, D., Makanga, B., Orach Meza, F., Hecky, R.E., Balirwa, J., Ogutu Ohwayo, R., Verburg, P., Chapman, L., Muhumuza, E., 2010. Intra-lake stable isotope ratio variation in selected fish species and their possible carbon sources in Lake Kyoga (Uganda): implications for aquatic food web studies. Afr J Ecol 48, 667-675.

McIntyre, J.K., Beauchamp, D.A., Mazur, M.M., Overman, N.C., 2006. Ontogenetic trophic interactions and benthopelagic coupling in Lake Washington: evidence from stable isotopes and diet analysis. Trans. Am. Fish. Soci. 135, 1312-1328.

Morgan, P., Aplet, G., Haufler, J., Humphries, H., Moore, M., Wilson, W., 1994. Historical range of variability: a useful tool for evaluating ecosystem change. J Sust Forestry 2, 87-111.

Murphy, K.R., Myors, B., 2004. Statistical Power Analysis: A Simple and General Model for Traditional and Modern Hypothesis Testing. Lawrence Erlbaum Associates, Mahwah, NJ.

Ocock, J., Baasanjav, G., Baillie, J.E.M., Erdenebat, M., Kottelat, M., Mendsaikhan, B., Smith, K., 2006. Mongolian Red List of Fishes. Zoological Society of London, London.

Olden, J.D., Jensen, O.P., Vander Zanden, M.J., 2006. Implications of long-term dynamics of fish and zooplankton communities for among-lake comparisons. Can J Fish Aquat Sci 63, 1812-1821.

Perga, M.E., Gerdeaux, D., 2005. “Are fish what they eat” all year round? Oecologia 144, 598-606.

Persson, L., 1986. Effects of reduced interspecific competition on resource utilization in perch (Perca fluviatilis). Ecology 355-364.

Persson, L., 1987. Effects of habitat and season on competitive interactions between roach (Rutilus rutilus) and perch (Perca fluviatilis). Oecologia 73, 170-177.

Persson, L., Eklov, P., 1995. Prey refuges affecting interactions between piscivorous perch and juvenile perch and roach. Ecology 76, 70-81.

Persson, L., Greenberg, L., 1990. Juvenile competitive bottlenecks: the perch (Perca fluviatilis)-roach (Rutilus rutilus) interaction. Ecology $44-$ 56.

Peterman, R., 1990. Statistical power analysis can improve fisheries research and management. Can J Fish Aquat Sci 47, 2-15.

Peterson, B., Fry, B., 1987. Stable isotopes in ecosystem studies. Annu Rev Ecol Evol Syst 18, 293-320.

Polacek, M.C., Baldwin, C.M., Knuttgen, K., 2006. Status, distribution, diet, and growth of burbot in Lake Roosevelt, Washington. Northwest Sci $80,153-164$.

Population and Housing Census of Mongolia, 2010. http://www.toollogo2010.mn/doc/bag,horoogoor.pdf (accessed 2/11/2014).

Post, D.M., 2002. Using stable isotopes to estimate trophic position: models, methods, and assumptions. Ecology 83, 703-718.

R Core Team, 2013. R: A language and environment for statistical computing.

Rask, M., 1986. The diet and diel feeding activity of perch, Perca fluviatilis L., in a small lake in southern Finland. Ann. Zool. Fennici $23,49-56$.

Roset, N., Grenouillet, G., Goffaux, D., Pont, D., Kestemont, P., 2007. A review of existing fish assemblage indicators and methodologies. Fish Manage 14, 393-405.

Rusak, J., Yan, N., Somers, K., Cottingham, K., Micheli, F., Carpenter, S., Frost, T., Paterson, M., McQueen, D., 2002. Temporal, spatial, and taxonomic patterns of crustacean zooplankton variability in unmanipulated north-temperate lakes. Limnol Oceanogr 47, 613-625.

Schindler, D.E., Scheuerell, M., 2002. Habitat coupling in lake ecosystems. Oikos 98, 177-189.

Schmidt, S.N., Vander Zanden, M.J., Kitchell, J.F., 2009. Long-term food web change in Lake Superior. Can J Fish Aquat Sci 66, $2118-2129$. 
Searle, S., 1971. Topics in variance component estimation. Biometrics 27, 1-76.

Sideleva, V.G., 2006. Chapter 22: Fish fauna of Lake Hövsgöl and Selenga River in comparison with icthyofauna of Lake Baikal, in: Goulden, C.E., Sitnikov, T., Gelhaus, J., Boldgiv, B. (Eds.), The Geology, Biodiversity and Ecology of Lake Hövsgöl. Backhuys Publishers, Leiden, the Netherlands, pp. 357-378.

Sierszen, M.E., Hrabik, T.R., Stockwell, J.D., Cotter, A.M., Hoffman, J.C., Yule, D.L., 2014. Depth gradients in food-web processes linking habitats in large lakes: Lake Superior as an exemplar ecosystem. Freshw Biol 59, 2122-2136.

Sierszen, M.E., McDonald, M., Jensen, D., 2003. Benthos as the basis for arctic lake food webs. Aquat Ecol 37, 437-445.

Sierszen, M.E., Peterson, G.S., Scharold, J.V., 2006. Depth-specific patterns in benthic--planktonic food web relationships in Lake Superior. Can J Fish Aquat Sci 63, 1496-1503.

Smol, J., 1992. Paleolimnology: an important tool for effective ecosystem management. J Aquat Ecosyst Health 1, 49-58.

Sokal, R., Braumann, C., 1980. Significance tests for coefficients of variation and variability profiles. Syst. Biol. 29, 50-66.

Solomon, C.T., Carpenter, S.R., Rusak, J.A., Vander Zanden, M.J., 2008. Long-term variation in isotopic baselines and implications for estimating consumer trophic niches. Can J Fish Aquat Sci 65, 2191-2200.

Sweeting, C.J., Polunin, N.V.C., Jennings, S., 2006. Effects of chemical lipid extraction and arithmetic lipid correction on stable isotope ratios of fish tissues. Rapid Commun. Mass Spectrom. 20, 595-601.

Syväranta, J., Hamalainen, H., Jones, R.I., 2006. Within-lake variability in carbon and nitrogen stable isotope signatures. Freshw Biol 51, 10901102.

Thomas, L., Juanes, F., 1996. The importance of statistical power analysis: an example from Animal Behaviour. Anim. Behav. 52, 856-859.

Vadeboncoeur, Y., McCann, K.S., Vander Zanden, M.J., Rasmussen, J.B., 2005. Effects of multi-chain omnivory on the strength of trophic control in lakes. Ecosystems 8, 682-693.

Vadeboncoeur, Y., McIntyre, P.B., Vander Zanden, M.J., 2011. Borders of biodiversity: life at the edge of the world's large lakes. BioScience 61, $526-537$.

Vander Zanden, M.J., Cabana, G., Rasmussen, J.B., 1997. Comparing trophic position of freshwater fish calculated using stable nitrogen isotope ratios $\left(\delta^{15} \mathrm{~N}\right)$ and literature dietary data. Can J Fish Aquat Sci 54, 1142-1158.

Vander Zanden, M.J., Casselman, J., Rasmussen, J.B., 1999. Stable isotope evidence for the food web consequences of species invasions in lakes. Nature 401, 464-467.

Vander Zanden, M.J., Chandra, S., Allen, B.C., Reuter, J.E., Goldman, C.R., 2003. Historical food web structure and restoration of native aquatic communities in the Lake Tahoe (California-Nevada) Basin. Ecosystems 6, 274-288.

Vander Zanden, M.J., Vadeboncoeur, Y., 2002. Fishes as integrators of benthic and pelagic food webs in lakes. Ecology 83, $2152-2161$.

Vander Zanden, M.J., Vadeboncoeur, Y., Chandra, S., 2011. Fish reliance on littoral-benthic resources and the distribution of primary production in lakes. Ecosystems 14, 894-903.

Weidel, B.C., Carpenter, S.R., Kitchell, J.F., Vander Zanden, M.J., 2011. Rates and components of carbon turnover in fish muscle: insights from bioenergetics models and a whole-lake 13C addition. Can J Fish Aquat Sci 68, 387-399.

Werner, E., Hall, D., 1988. Ontogenetic habitat shifts in bluegill: the foraging rate-predation risk trade-off. Ecology 1352-1366.

Williams, D., Evans, R., West, J., Ehleringer, J., 2007. Applications of stable isotope measurements for early-warning detection of ecological 
change. Terr. Ecol. 1, 383-398.

Yoshii, K., 1999. Stable isotope analyses of benthic organisms in Lake Baikal. Hydrobiologia 411, 145-159.

Yoshii, K., Melnik, N., Timoshkin, O., Bondarenko, N., Anoshko, P., Yoshioka, T., Wada, E., 1999. Stable isotope analyses of the pelagic food web in Lake Baikal. Limnol Oceanogr 502-511. 


\section{Table 1}

Fish species sampled in Lake Hövsgöl and common prey items for those species. Hövsgöl grayling are endemic and considered endangered (Ocock et al., 2006). Other fish species found in the lake but not included in this analysis are Baikal grayling (Thymallus arcticus baicalensis), Siberian stone loach (Barbatula toni), spiny loach (Cobitis melanoleuca), and Baikal omul (Coregonus autumnalis migratorius) (Sideleva, 2006).

\begin{tabular}{|c|c|c|}
\hline Common name & Scientific name & Common prey items \\
\hline burbot & Lota lota & $\begin{array}{l}\text { Fish, benthic invertebrates, insects, } \\
\text { zooplankton (Amundsen et al., 2003; } \\
\text { Fratt et al., 2001; Jacobs et al., 2010; } \\
\text { Polacek et al., 2006; Sideleva, 2006) }\end{array}$ \\
\hline Eurasian minnow & Phoxinus phoxinus & $\begin{array}{l}\text { Zooplankton, benthic and terrestrial } \\
\text { invertebrates, insects, fish eggs (Frost, } \\
\text { 1943; Sideleva, 2006) }\end{array}$ \\
\hline Eurasian perch & Perca fluviatilis & $\begin{array}{l}\text { Fish, zooplankton, insects, benthic } \\
\text { invertebrates (Persson and Eklov, 1995; } \\
\text { Rask, 1986; Sideleva, 2006) }\end{array}$ \\
\hline Hövsgöl grayling & Thymallus nigrescens & $\begin{array}{l}\text { Zooplankton, benthic and terrestrial } \\
\text { invertebrates (Ahrenstorff et al., 2011; } \\
\text { Sideleva, 2006) }\end{array}$ \\
\hline lenok & Brachymystax lenok & $\begin{array}{l}\text { Zooplankton, benthic and terrestrial } \\
\text { invertebrates, fish and terrestrial } \\
\text { invertebrates (Chandra et al., 2005a; } \\
\text { Sideleva, 2006) }\end{array}$ \\
\hline roach & Rutilus rutilus & $\begin{array}{l}\text { Plants, benthic invertebrates, } \\
\text { zooplankton (Persson, 1987; Sideleva, } \\
\text { 2006) }\end{array}$ \\
\hline
\end{tabular}


Table 2

Stable isotope values $\left(\delta^{13} \mathrm{C}\right.$ and $\delta^{15} \mathrm{~N}$ ) (mean, SD, absolute value of $\mathrm{CV}, \%$ littoral-benthic reliance and trophic position: mean and SD, plus sample sizes) for fish collected from Lake Hövsgöl, Mongolia over all seven collection sites and five years $(2006,2009,2011,2012,2013)$.

\begin{tabular}{|c|c|c|c|c|c|c|c|c|c|c|c|}
\hline & \multirow[b]{2}{*}{$\mathrm{n}$} & \multicolumn{3}{|c|}{$\delta^{13} \mathrm{C}$} & \multicolumn{2}{|c|}{$\begin{array}{l}\text { Littoral- } \\
\text { benthic } \\
\text { reliance }\end{array}$} & \multicolumn{3}{|c|}{$\delta^{15} \mathrm{~N}$} & \multicolumn{2}{|c|}{$\begin{array}{l}\text { Trophic } \\
\text { position }\end{array}$} \\
\hline & & Mean & SD & CV & Mean & SD & Mean & SD & CV & Mean & SD \\
\hline \multicolumn{12}{|l|}{ Fish } \\
\hline burbot & 64 & -21.3 & 0.9 & 0.0 & $84 \%$ & $11 \%$ & 8.3 & 0.9 & 0.1 & 3.4 & 0.3 \\
\hline Eurasian minnow & 33 & -22.4 & 1.8 & 0.1 & $71 \%$ & $19 \%$ & 7.8 & 1.0 & 0.1 & 3.2 & 0.3 \\
\hline Eurasian perch & 47 & -24.2 & 2.5 & 0.1 & $48 \%$ & $31 \%$ & 9.3 & 0.8 & 0.1 & 3.7 & 0.3 \\
\hline Hövsgöl grayling & 134 & -23.0 & 1.7 & 0.1 & $63 \%$ & $20 \%$ & 6.6 & 0.6 & 0.1 & 2.9 & 0.2 \\
\hline lenok & 83 & -22.0 & 2.2 & 0.1 & $75 \%$ & $23 \%$ & 7.8 & 0.9 & 0.1 & 3.2 & 0.3 \\
\hline roach & 69 & -26.6 & 3.5 & 0.1 & $29 \%$ & $32 \%$ & 8.2 & 0.9 & 0.1 & 3.4 & 0.3 \\
\hline \multicolumn{12}{|l|}{ Baselines } \\
\hline $\begin{array}{l}\text { littoral-benthic } \\
\text { (snail) }\end{array}$ & 20 & -20.1 & 3.6 & 0.2 & & & 3.8 & 1.0 & 0.3 & & \\
\hline $\begin{array}{l}\text { pelagic } \\
\text { (zooplankton) }\end{array}$ & 10 & -28.7 & 1.6 & 0.1 & & & 3.6 & 0.3 & 0.1 & & \\
\hline
\end{tabular}




\section{Table 3}

Sample sizes (n) and model performance metrics of mixed effects models for each species. Model performance metrics included AIC values of the full model and $\triangle \mathrm{AIC}$ between the full model and the location model or year model. The full model for each species included $\delta^{13} \mathrm{C}$ or $\delta^{15} \mathrm{~N}$ as the response variable, location and year as random intercept effects and length as a continuous fixed effect. The location model included only location and length, and the year model included only year and length. Gray highlighting indicates instances where either the location or year models were a poorer fit $(\triangle \mathrm{AIC}>2)$ than the full model. *We did not include length in the models for perch and roach.

\begin{tabular}{|c|c|c|c|c|}
\hline & \multirow[t]{4}{*}{$\mathbf{n}$} & AIC & \multicolumn{2}{|c|}{$\Delta$ AIC } \\
\hline & & Full model & $\begin{array}{c}\text { Location } \\
\text { model } \\
\text { (without } \\
\text { year) }\end{array}$ & $\begin{array}{c}\text { Year } \\
\text { model } \\
\text { (without } \\
\text { location) }\end{array}$ \\
\hline & & \multicolumn{3}{|c|}{ Model structure } \\
\hline & & $\begin{array}{c}\text { location } \\
+ \\
\text { year } \\
+ \\
\text { length }\end{array}$ & $\begin{array}{c}\text { location } \\
+ \\
\text { length }\end{array}$ & $\begin{array}{c}\text { year } \\
+ \\
\text { length* }\end{array}$ \\
\hline \multicolumn{5}{|l|}{ Carbon } \\
\hline burbot & 64 & 145.18 & -1.46 & 4.38 \\
\hline Eurasian perch* & 47 & 206.16 & -2.00 & 14 \\
\hline Hövsgöl grayling & 102 & 387.97 & 0.03 & 10.17 \\
\hline lenok & 79 & 298.61 & -1.98 & 0.28 \\
\hline roach * & 69 & 359.46 & 5.05 & 12.35 \\
\hline \multicolumn{5}{|l|}{ Nitrogen } \\
\hline burbot & 64 & 129.3 & -1.37 & -1.31 \\
\hline Eurasian perch* & 47 & 112.11 & 0.34 & 3.75 \\
\hline Hövsgöl grayling & 102 & 175.93 & -1.66 & -1.8 \\
\hline lenok & 79 & 203.86 & 7.48 & -0.77 \\
\hline roach* & 69 & 176.58 & -2.00 & 6.95 \\
\hline
\end{tabular}


Fig. 1

Lake Hövsgöl, with collection locations. We sampled at both littoral and pelagic sites at most collection locations $(2,6,8,7 \mathrm{a}, 7 \mathrm{~b}, 9)$. Two collection locations $(1,3)$ included only littoral sampling while two other collection locations $(4,5)$ included only pelagic sampling.

\section{Fig. 2}

Stable isotope food web biplot ( $\delta^{13} \mathrm{C}$ vs. $\delta^{15} \mathrm{~N}$ ) of six fish species in Lake Hövsgöl, Mongolia over all years and locations. Animal shapes indicate grand means over all collection years and ellipses are standard ellipses, indicating approximately $40 \%$ of points (Batschelet, 1981). Shaded regions indicate $\delta^{13} \mathrm{C}$ range of annual baseline means (pelagic: zooplankton, littoral-benthic: snails) and year numbers indicate mean values for that year.

\section{Fig. 3}

(a-e) $\delta^{13} \mathrm{C}$ and (f-j) $\delta^{15} \mathrm{~N}$ values by total fish length, with linear regression lines and significance values. We excluded Eurasian minnows from this analysis because we had too few length measurements for that species. 


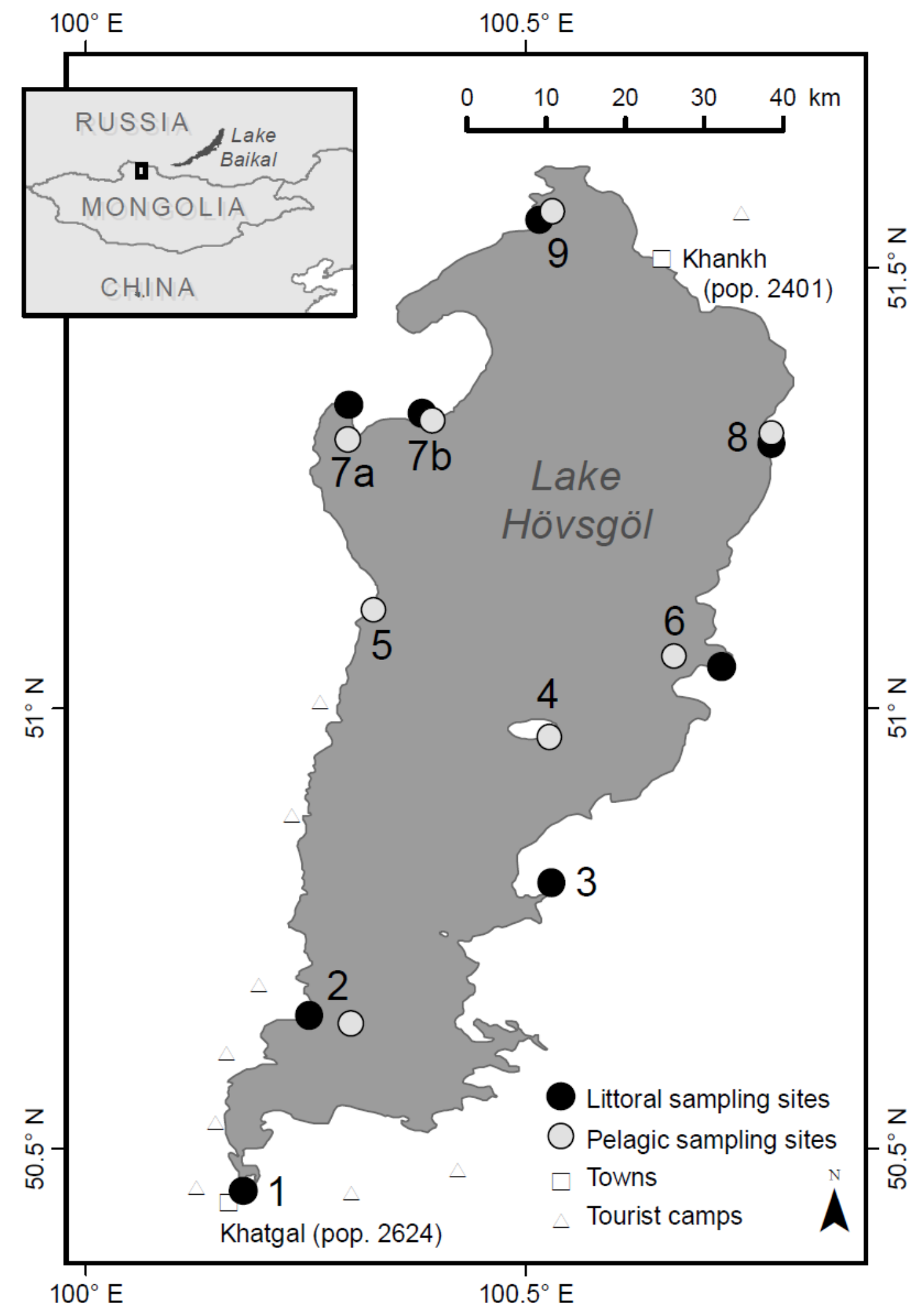

Figure 1 


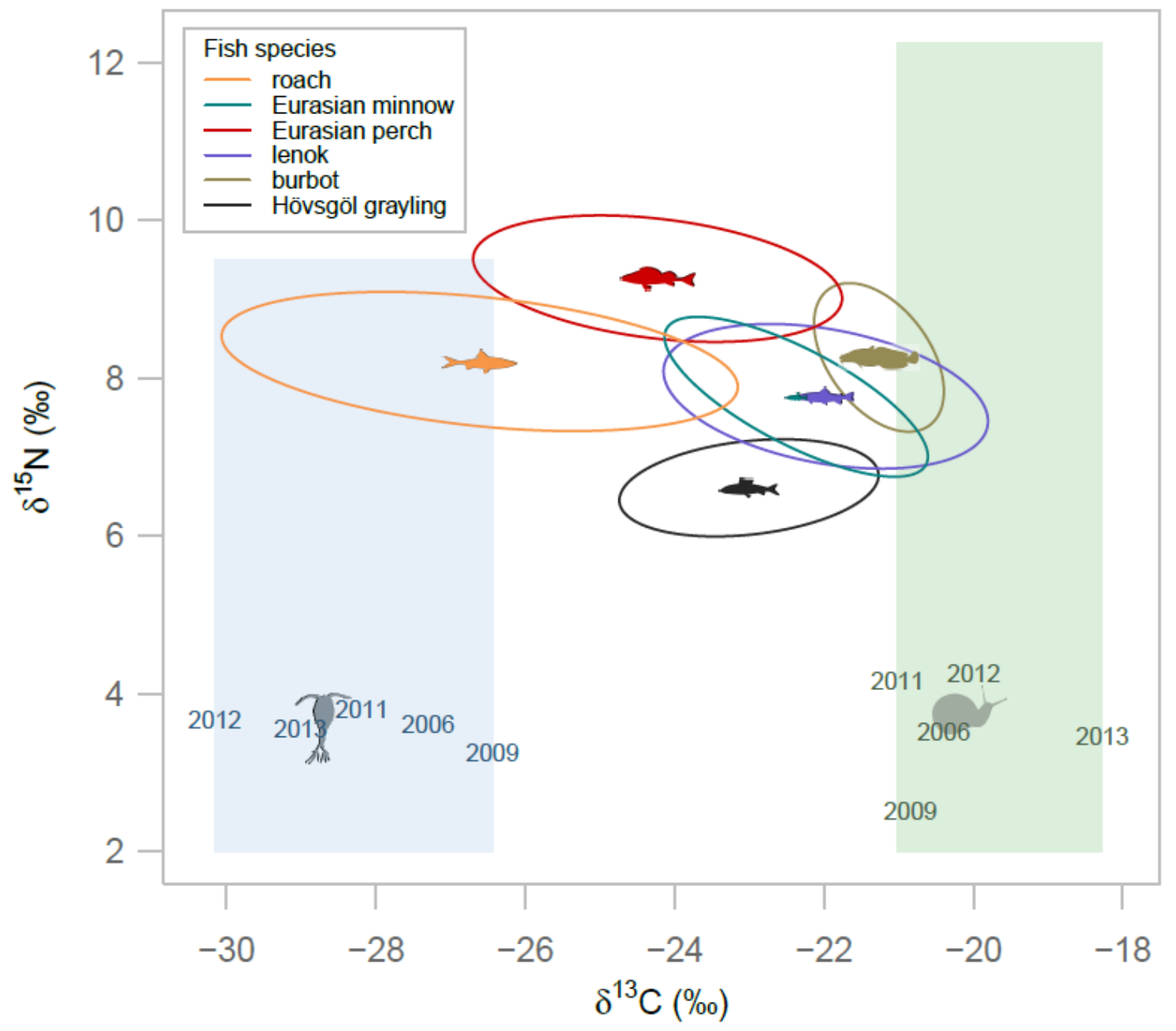

Figure 2 


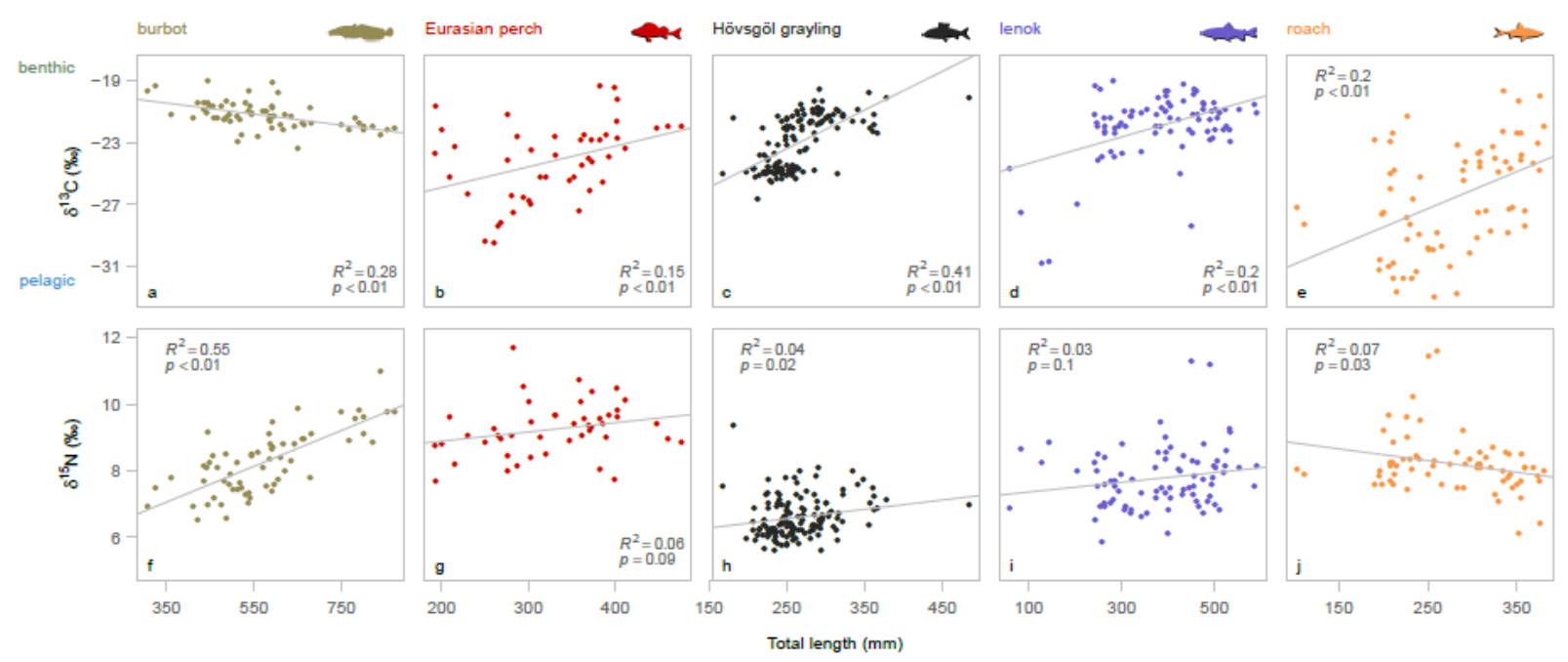

Figure 3 


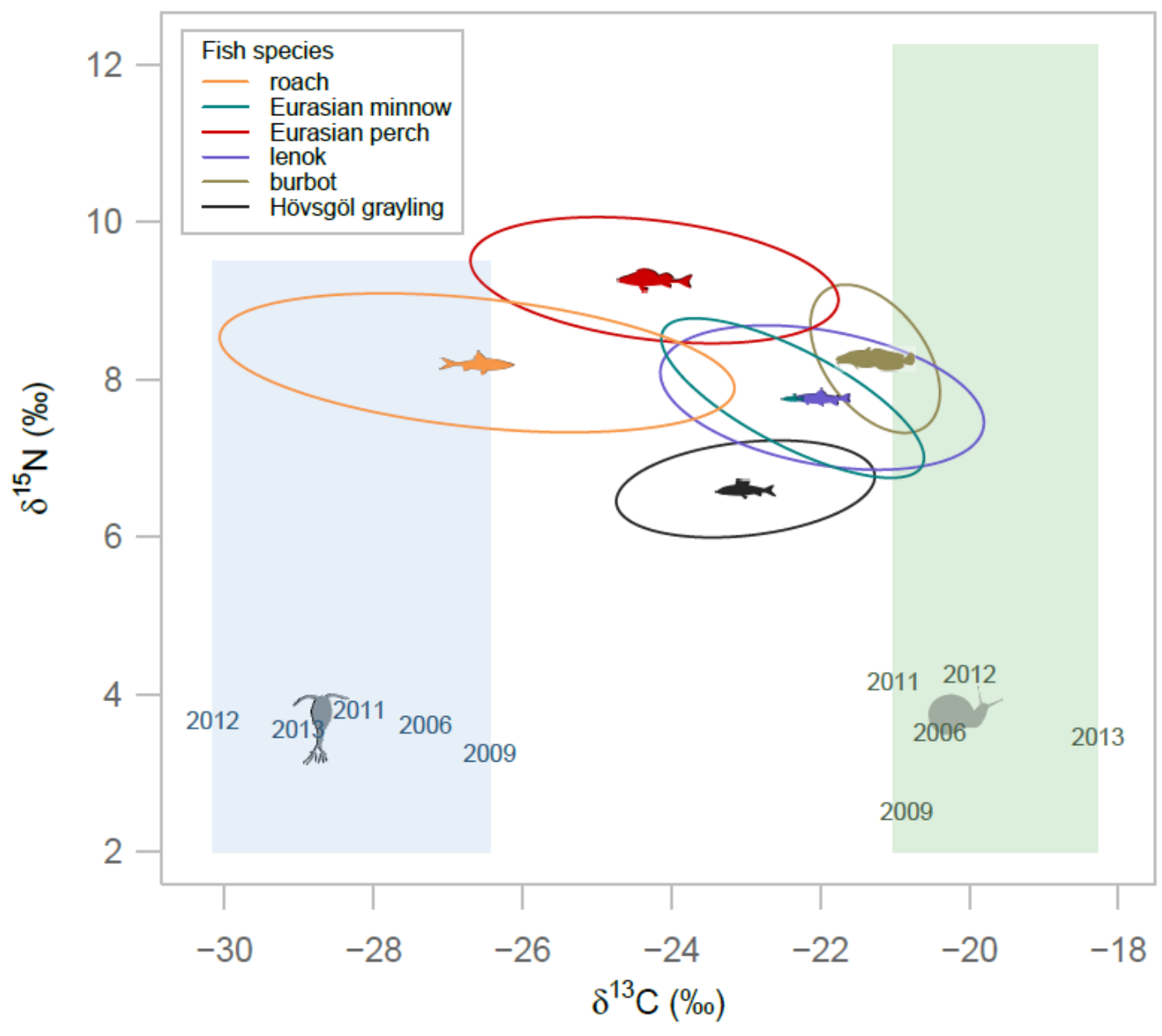

Graphical abstract 